\title{
Pengaruh kinerja keuangan terhadap dividend payout ratio studi empiris pada perusahaan BUMN
}

\author{
Fitri Handayani Sabri' ${ }^{1}$, Dwi Risma Deviyanti ${ }^{2}$, Indra Suyoto Kurniawan ${ }^{3}$ \\ Fakultas Ekonomi dan Bisnis Universitas Mulawarman, Samarinda. \\ ${ }^{1}$ Email: handayanifitri94@gmail.com \\ ${ }^{2}$ Email: dwi.risma.deviyanti@feb.unmul.ac.id \\ ${ }^{3}$ Email: indra.suyoto.kurniawan@feb.unmul.ac.id
}

\begin{abstract}
Abstrak
Tujuan penelitian ini adalah untuk menganalisis pengaruh Rasio Cash Ratio, Debt to Equity Ratio (DER), Total Assets Turnover (TATO) dan Net Profit Margin (NPM) terhadap Dividen Payout Ratio (DPR) pada perusahaan BUMN yang terdaftar di BEI over periode 2011-2014. Teknik pengambilan sampel yang digunakan disini adalah purposive sampling. Teknik analisis yang digunakan di sini adalah regresi berganda dengan uji hipotesis menggunakan teknik t-statistik untuk menguji koefisien regresi parsial dengan tingkat signifikansi 0,05 atau 5\%. Dari hasil analisis, terlihat bahwa variabel Rasio Kewajiban terhadap Rasio Hutang terhadap Ekuitas (Ratio) terhadap Total Assets Turnover (TATO) secara parsial berpengaruh terhadap Dividen Payout Ratio (DPR) perusahaan pada periode 2011-2014 pada tingkat signifikansi kurang dari 5\%, sementara itu menunjukkan bahwa Rasio Cash Ratio dan Net Profit Margin (NPM) secara parsial tidak signifikan terhadap Dividen Payout Ratio (DPR). Prediksi empat variabel terhadap DPR adalah 43,9\% seperti yang ditunjukkan oleh adjusted square yaitu 43,9\% sedangkan sisanya 56,1\% dipengaruhi oleh faktor lain yang tidak termasuk dalam model studi.
\end{abstract}

Kata Kunci: Rasio kas

\section{Pengaruh kinerja keuangan terhadap dividend payout ratio studi empiris pada perusahaan BUMN}

\begin{abstract}
The objective this study is to analyze the effect of Cash Ratio, Debt to Equity Ratio (DER), Total Assets Turnover (TATO) and Net Profit Margin (NPM) toward Dividend Payout Ratio (DPR) in BUMN company which is listed in BEI over period 2011-2014. Sampling technique used here is purposive sampling. The analysis technique used here is multiple regressions with hypothesis tes using $t$-statistic technique to examine partial regression coefficient with level of significance 0,05 or 5\%. From the analysis result, it indicates that Debt to Equity Ratio (DER) and Total Assets Turnover (TATO) variabel partially significant toward Dividend Payout Ratio (DPR) of the company on 2011-2014 period on the level of significance less than 5\%, while it indicates that Cash Ratio and Net Profit Margin (NPM) variabel partially not significant toward Dividend Payout Ratio (DPR). Predictable of four variables toward DPR is $43,9 \%$ as indicated by adjusted $R$ square that is $43,9 \%$ while the rest $56,1 \%$ is affected by other factors which are not included into the study model.
\end{abstract}

Keywords: Cash Ratio 


\section{PENDAHULUAN}

Aktivitas investasi merupakan aktivitas yang dihadapkan pada berbagai macam risiko dan ketidakpastian yang sering kali sulit diprediksikan oleh para investor. Untuk mengurangi kemungkinan risiko dan ketidakpastian yang akan terjadi, investor memerlukan berbagai macam informasi, baik informasi yang diperoleh dari kinerja perusahaan maupun informasi lain yang relevan seperti kondisi ekonomi dan politik dalam suatu negara. Informasi yang diperoleh dari perusahaan lazimnya didasarkan pada kinerja perusahaan yang tercermin dalam laporan keuangan (Laksono, 2006 dalam Difah, 2011).

Perusahaan harus menentukan kebijakan yang tepat untuk menangani masalah yang terkait dengan dividen. Masing-masing perusahaan menetapkan kebijakan dividen yang berbeda-beda. Perusahaan perlu membuat kebijakan tentang besarnya laba yang akan dibagikan kepada pemegang saham atau biasa disebut Dividend Payout Ratio (DPR), dan besarnya laba yang akan ditahan oleh perusahaan. Semakin besar laba yang dibagikan dalam bentuk dividen akan semakin menarik bagi calon investor. Ini karena para calon investor menilai bahwa perusahaan dalam kondisi yang sehat dan memiliki prospek yang baik di masa mendatang.

Badan Usaha Milik Negara atau biasa disingkat sebagai BUMN memiliki peran yang penting bagi negara. Badan Usaha Milik Negara adalah badan usaha yang sebagian atau seluruh kepemilikannya dimiliki oleh Negara Republik Indonesia, dimana pemegang saham terbesarnya berasal dari pemerintah.

Perusahaan BUMN memiliki perilaku yang berbeda dengan perusahaan swasta dalam hal pembagian dividen. Besarnya dividen ditentukan dalam RUPS (Rapat Umum Pemegang Saham), dalam perusahaan BUMN, pemerintah sebagai pemegang saham terbesar sangat menentukan besarnya dividen yang dibayarkan. Sedangkan, pada perusahaan swasta tidak demikian. Besar kecilnya dividen dalam perusahaan swasta dipengaruhi oleh para pemegang saham yang tidak berasal dari pemerintah (Difah, 2011).

Dividen peruahaan BUMN merupakan hal yang penting untuk dibahas karena akan sangat berpengaruh terhadap pendapatan negara dalam APBN. Porsi pembayaran dividen perusahaan BUMN selama periode 2011-2014 berfluktuatif.

\section{Tinjauan Pustaka}

\section{Manajemen Keuangan}

Menurut Martono dan Agus (2010) mendefinisikan manajemen keuangan adalah segala aktivitas perusahaan yang berhubungan dengan bagaimana memperoleh dana, mengelola aset sesuai tujuan perusahaan secara menyeluruh. Adapun menurut Husnan (2008) manajemen keuangan menyangkut kegiatan perencanaan, analisis dan pengendalian kegiatan keuangan dalam satu organisasi.

\section{Dividen}

Dividen adalah pembagian laba yang diperoleh perusahaan kepada para pemegang saham yang sebanding dengan jumlah saham yang dimiliki. Dividen akan diterima oleh pemegang saham hanya apabila usaha akan menghasilkan cukup uang untuk membagi dividen tersebut dan apabila dewan direksi menganggap layak bagi perusahaan untuk mengumumkan dividen. Pendapatan yang diharapkan oleh pemegang saham adalah pendapatan yang dihasilkan dari pembagian dividen, dimana badan usaha menyerahkan sebagian labanya, untuk kepentingan kesejahteraan pemegang saham (Marietta, 2013).

Dividen yang akan dibagikan oleh perusahaan dapat terbagi dalam beberapa jenis, yaitu:

1. Dividen Tunai (cash dividend)

2. Dividen Saham (stock dividend)

3. Dividen Saham Pecahan (stock split)

4. Dividen Script

5. Dividen Properti (property dividend)

6. Dividen Likuidasi (liquidating dividend)

\section{Kebijakan Dividen}

Menurut Sutrisno (2009), kebijakan dividen adalah kebijakan yang harus diambil oleh manajemen untuk memutuskan apakah laba yang diperoleh oleh perusahaan selama satu periode akan dibagi semua atau dibagi sebagian untuk dividen dan sebagian lagi tidak dibagi dalam bentuk laba ditahan. 


\section{1) Faktor yang Mempengaruhi Kebijakan Dividen:}
a) Kebutuhan untuk melunasi hutang
b) Tingkat Ekspansi Aktiva
c) Tingkat laba
d) Stabilitas Laba
e) Peluang ke Pasar Modal

2) Teori Kebijakan Dividen
a) Residual Dividend of Theory
b) Walter's Dividend Model
c) Modigliani and Miller's Model

\section{Pengertian Rasio Keuangan}

Menurut Kasmir (2012), rasio keuangan merupakan kegiatan membandingkan angka- angka yang ada dalam laporan keuangan dengan cara membagi satu angka dengan angka lainnya. Perbandingan dapat dilakukan antara satu komponen dengan komponen dalam satu laporan keuangan atau antarkomponen yang ada di antara laporan keuangan. Kemudian angka yang diperbandingkan dapat berupa angka- angka dalam satu periode maupun berbeda periode.

\section{Analisis Rasio Keuangan}

Analisis rasio keuangan terhadap perusahaan digunakan untuk mengetahui keadaan dan perkembangan keuangan perusahaan terutama bagi pihak manajemen. Hasil analisa dapat digunakan untuk melihat kelemahan perusahaan selama periode waktu berjalan.

\section{Jenis Rasio Keuangan}

Untuk mengukur kinerja keuangan perusahaan menggunakan rasio keuangan dapat dilakukan dengan beberapa rasio keuangan. Berdasarkan jenis-jenis rasio keuangan yang telat disebutkan di atas, penulis menggunakan keempat rasio keuangan dalam penelitian ini. Rasio-rasio tersebut adalah:

\section{Rasio Likuiditas}

Rasio likuiditas yaitu ratio yang digunakan untuk menganalisa dan menginterprestasikan posisi keuangan jangka pendek, tetapi sangat membantu management untuk mengecek efisiensi modal kerja yang digunakan dalam perusahaan Munawir (2010). Rasio yang digunakan dalam menghitung tingkat likuiditas suatu perusahaan dalam penelitian ini adalah Cash Ratio (CR). Cash ratio merupakan salah satu ukuran dari rasio likuiditas (liquidity ratio) yang merupakan kemampuan perusahaan memenuhi kewajiban jangka pendeknya (current liability) melalui sejumlah kas dan setara kas yang dimiliki perusahaan.

\section{Rasio Solvabilitas}

Menurut Munawir (2010) "Rasio Leverage yaitu ratio untuk mengukur sampai seberapa jauh aktiva perusahaan dibiayai dari hutang". Artinya berapa besar beban utang yang ditanggung perusahaan dibandingkan dengan aktivanya. Dalam penelitian ini, rasio yang digunakan adalah Debt to Equity Ratio (DER), ini mengukur leverage keuangan yang sedang digunakan oleh sebuah perusahaan, seberapa jauh perusahaan tersebut dibiayai oleh hutang.

\section{Rasio Aktivitas}

Menurut Kasmir (2012) "Rasio aktivitas (activity ratio) merupakan rasio yang digunakan untuk mengukur efektivitas perusahaan dalam menggunakan aktiva yang dimilkinya". Dalam penelitian ini, rasio yang digunakan adalah Total Assets Turnover (TATO). Rasio perputaran total aktiva atau sering disebut sebagai Total Assets Turnover (TATO) merupakan rasio yang digunakan untuk mengukur perputaran semua aktiva yang dimiliki perusahaan dan mengukur berapa jumlah penjualan yang diperoleh dari tiap rupiah aktiva (Kasmir, 2012). 


\section{Rasio Profitabilitas}

Untuk mengukur tingkat keuntungan suatu perusahaan, digunakan rasio profitabilitas atau dikenal dengan nama rasio rentabilitas. Dalam penelitian ini, profitabilitas diukur dengan Net Profit Margin (NPM). Rasio ini digunakan untuk mengukur kemampuan perusahaan dalam menghasilkan net income dari operasi pokok perusahaan. Semakin tinggi nilai NPM berarti semakin baik perusahaan menghasilkan laba, sehingga semakin tinggi pula dividen yang dapat dibayarkan perusahaan.

\section{Dividend Payout Ratio}

Salah satu faktor penting yang menunjukkan besarnya nilai dividen yang dibagikan oleh perusahaan kepada stakeholder adalah dividend payout ratio (DPR). Rasio pembayaran dividen yaitu dividen tunai tahunan yang dibagi dengan laba tahunan; atau, dividen per lembar saham dibagi dengan laba per lembar saham. Rasio tersebut menunjukkan persentase laba perusahaan yang dibayarkan kepada pemegang saham secara tunai. (Home \& Wachowicz, JR. 2010).

\section{Penelitian Terdahulu}

a. Sunarto dan Kartika (2003) judul penelitian Analisis faktor-faktor yang mempengaruhi dividen kas di Bursa Efek Jakarta Periode 1999 - 2000. Variabel independen yang digunakan adalah ROI, cash ratio, current ratio, Debt to Total Assets (DTA) dan Earning per Share (EPS). Hasil penelitian menunjukkan bahwa hanya EPS berpengaruh positif dan signifikan terhadap dividen kas, sedangkan untuk variabel lain yaitu cash ratio, current ratio, DTA, dan ROI berpengaruh negatif dan tidak signifikan.

b. Purwanti dan Sawitri (2011) melakukan penelitian tentang : Dampak Rasio Keuangan terhadap Kebijakan Dividen Pada Perusahaan Manufaktur di Bursa Efek Indonesia. Hasil penelitian menunjukkan variabel Earning Per Share, Debt to Equity Ratio, Return On Investment, dan Total Assets Turnover berpengaruh positif dan signifikan berpengaruh terhadap Dividend Payout Ratio.

c. Rejeki dan Endang (2011) melakukan penelitian dengan judul "Pengaruh Debt to Equity Ratio, Net Profit Margin, Asset Growth, Firm Size dan Current Ratio terhadap Dividend Payout Ratio". Studi kasus pada perusahaan Non Financial yang terdaftar di BEI periode 2005-2009. Hasil penelitian menunjukkan Net Profit Margin, Firm Size berpengearuh positif dan signifikan terhadap Dividend Payout Ratio. Sedangkan Debt to Equity Ratio, Asset Growth dan Current Ratio berpengaruh negatif dan tidak signifikan terhadap Dividend Payout Ratio

\section{Hipotesis}

H1 : Cash Ratio (CR) berpengaruh terhadap Dividend Payout Ratio (DPR).

H2 : Debt to Equity Ratio (DER) berpengaruh terhadap Dividend Payout Ratio (DPR).

H3 : Total Assets Turnover (TATO) berpengaruh terhadap Dividend Payout Ratio (DPR).

H4 : Net Profit Margin (NPM) berpengaruh terhadap Dividend Payout Ratio (DPR).

\section{METODE}

\section{Definisi Operasional Variabel dan Pengukuran Variabel}

Penelitian ini melibatkan variabel yang terdiri dari empat variabel bebas (independen) dan satu variabel terikat (dependen). Variabel independen dalam penelitian ini Cash Ratio, Debt to Equity Ratio, Total Assets Turnover dan Net Profit Margin, serta satu variabel dependen yaitu Dividend Payout Ratio (DPR).

\section{Dividend Payout Ratio (Y)}

Dividend Payout Ratio (DPR) adalah nilai rasio perbandingan antara laba yang dibagi perusahaan dalam bentuk dividen per lembar saham (dividend per share) dibagi laba per lembar saham (earning per share) (Horne \& Wachowicz, 2010) pada perusahaan BUMN yang terdaftar di Bursa Efek Indonesia.

$\mathrm{DPR}=\frac{\text { Divlden per lembar saham }}{\text { Laba per lembar saham }} \times 100 \%$ 


\section{Populasi dan Sampel}

Populasi yang digunakan dalam penelitian ini adalah seluruh perusahaan BUMN yang terdaftar di Bursa Efek Indonesia (BEI) dari tahun 2011-2014 yang mempublikasikan laporan tahunan di IDX (Indonesian Stock Exchange) tahun 2011-2014. Pengambilan sampel pada penelitian ini menggunakan metode purposive sampling yaitu pengambilan sampel sesuai dengan kriteria tertentu. Adapun kriteria pengambilan sampel adalah sebagai berikut:

a. Perusahaan BUMN yang terdaftar di Bursa Efek Indonesia selama periode penelitian yaitu tahun 2011 sampai dengan 2014.

b. Perusahaan BUMN yang terdaftar di Bursa Efek Indonesia yang telah mempublikasikan laporan tahunan pada IDX (Indonesia Stock Exchange) secara kontinyu dari tahun 2011 sampai dengan 2014.

b) Perusahaan sampel yang membagikan dividen selama empat tahun berturut-turut pada tahun 2011-2014.

\section{Jenis Data dan Sumber Data}

Jenis data yang digunakan dalam penelitian ini adalah data kuantitatif berupa data dalam laporan tahunan perusahaan BUMN yang terdaftar di Bursa Efek Indonesia pada tahun 2011, 2012, 2013 dan 2014. Sumber data yang digunakan ini adalah data sekunder merupakan sumber yang tidak langsung memberikan data kepada pengumpul data misalnya lewat orang lain atau lewat dakumen (Sugiyono, 2013). Data sekunder yang digunakan berupa laporan tahunan perusahaan sampel yang diperoleh dari situs resmi Bursa Efek Indonesia (http//www.idx.co.id).

\section{Metode Pengumpulan Data}

Teknik pengumpulan data untuk keperluan penelitian ini dilakukan dengan metode dokumentasi. Dokumentasi yang dilakukan adalah dengan mengumpulkan semua data sekunder yang dipublikasikan oleh Bursa Efek Indonesia melalui website www.idx.co.id.

\section{Deskripsi Objek Penelitian}

Objek penelitian yang digunakan dalam penelitian ini adalah Perusahaan BUMN yang terdaftar di Bursa Efek Indonesia selama periode 2011-2014 (4 tahun). Perusahaan BUMN memiliki bermacammacam sektor yang terdiri dari Sektor Farmasi, Energi, Konstruksi, Bank, Pertambangan, Semen, Angkutan dan Sektor Telekomunikasi. Dengan sampel yang diperoleh sebanyak 14 perusahaan. an periode penelitian tahun 2011-2014.

\section{HASIL DAN PEMBAHASAN}

Berdasarkan hasil penelitian yang menguji pengaruh Cash Ratio, Debt to Equity Ratio, Total Assets Turnover dan Net Profit Margin terhadap Dividend Payout Ratio perusahaan BUMN di atas, maka ada beberapa hal yang dapat dijelaskan dalam penelitian ini, yaitu sebagai berikut:

\section{Pengaruh Cash Ratio (X1) terhadap Dividend Payout Ratio (DPR)}

Cash Ratio adalah pembanding antara kas dan aktiva lancar yang bisa segera menjadi uang kas dengan hutang lancar. Uji-t variabel independen Cash Ratio tidak berpengaruh signifikan terhadap Dividend Payout Ratio. Hal ini dapat ditunjukkan dengan nilai thitung -1,133 dengan tingkat signifikansi 0,262 > 0,05 maka dapat diambil kesimpulan bahwa Cash Ratio tidak berpengaruh signifikan terhadap Dividend Payout Ratio (DPR). Cash Ratio mempunyai koefisien korelasi sebesar -0,150. Dimana $0,150<0$ sehingga dapat ditarik kesimpulan bahwa variabel cash ratio mempunyai arah pengaruh negatif terhadap Dividend Payout Ratio (DPR).

\section{Pengaruh Debt to Equity Ratio (DER) (X2) terhadap Dividend Payout Ratio (DPR)}

Debt to Equity Ratio (DER) menunjukkan seberapa besar kebutuhan dana perusahaan dibelanjai dengan hutang. Berdasarkan hasil penelitian variabel Debt to Equity Ratio (DER) berpengaruh secara signifikan terhadap Dividend Payout Ratio. Hal ini dapat ditunjukkan dengan nilai thitung $=-5,447$, dengan nilai signifikansi sebesar $0,000<0,05$. DER mempunyai koefisien korelasi sebesar $-0,036$. 
Dimana $-0,036<0$ sehingga dapat ditarik kesimpulan bahwa variabel Debt to Equity Ratio mempunyai arah pengaruh negatif terhadap variabel Y yaitu Dividend Payout Ratio (DPR).

\section{Pengaruh Total Assets Turnover (TATO) (X3) terhadap Dividend Payout Ratio (DPR)}

Rasio TATO yang rendah merupakan indikasi bahwa perusahaan tidak beroperasi pada volume yang memadai bagi kapasitas investasinya. Maka semakin besar perputaran aset semakin efektif perusahaan mengelola aktivanya. Hasil penelitian menunjukkan bahwa Total Assets Turnover (TATO) signifikan terhadap Dividend Payout Ratio. Sesuai dengan hasil pengujian nilai thitung sebesar -2,268, dengan nilai signifikansi sebesar $0,028<0,05$. Total Assets Turnover (TATO) mempunyai koefisien korelasi sebesar 0,176. Dimana 0,176 > 0 sehingga dapat ditarik kesimpulan bahwa variabel Total Assets Turnover mempunyai arah pengaruh positif terhadap variabel Y yaitu Dividend Payout Ratio (DPR).

\section{Pengaruh Net Profit Margin (NPM) (X4) terhadap Dividend Payout Ratio (DPR)}

Net Profit Margin atau margin laba bersih dalam penelitian ini dihitung dengan membandingkan laba bersih setelah pajak dengan penjualan. Dari Hasil Uji-t variabel independen Net Profit Margin tidak berpengaruh signifikan terhadap Dividend Payout Ratio. Hal ini dapat ditunjukkan dengan nilai thitung sebesar 0,167, dengan nilai signifikansi sebesar 0,300 >0,05. Net Profit Margin mempunyai koefisien korelasi sebesar 0,176. Dimana 0,176 >0 sehingga dapat ditarik kesimpulan bahwa variabel Net Profit Margin mempunyai arah pengaruh positif terhadap Dividend Payout Ratio (DPR).

\section{SIMPULAN}

1) Cash Ratio memberikan hasil bahwa Cash Ratio negatif dan tidak signifikan terhadap Dividend Payout Ratio (DPR) pada perusahaan BUMN.

2) Debt to Equity Ratio (DER) memiliki pengaruh negatif dan signifikan terhadap Dividend Payout Ratio (DPR) pada perusahaan BUMN.

3) Total Assets Turnover (TATO) memiliki pengaruh negatif dan signifikan terhadap Dividend Payout Ratio (DPR) pada perusahaan BUMN.

4) Net Profit Margin (NPM) memiliki pengaruh positif dan tidak signifikan terhadap Dividend Payout Ratio (DPR) pada perusahaan BUMN.

\section{DAFTAR PUSTAKA}

Ariyanti, Ikaida Wahyu. 2014. Pengaruh Total Assets Turnover (TATO), Inventory Turnover (ITO), Debt to Equity Ratio (DER), dan Earning Per Share (EPS) terhadap Dividend Payout Ratio (DPR), Artikel Publikasi Ilmiah. Fakultas Ekonomi. Universitas Muhammadiyah Surakarta.

Brigham dan Houston, 2010. Dasar-dasar Manajemen Keuangan Buku 1 (Edisi 11). Salemba Empat. Jakarta.

Charlina et al. 2014.“Analisis Variabel-Variabel yang Mempengaruhi Kebijakan Dividen”.Jurnal Administrasi Bisnis (JAB). 15 (1).

Difah, Siti Syamsiroh. 2011. Analisis Faktor-Faktor yang Mempengaruhi Dividend Payout

Ratio Pada Perusahaan BUMN yang Terdaftar Di Bursa Efek Indonesia Periode Tahun 2004-2009. Skripsi. Universitas Diponegoro.

Ghozali, Imam. 2011. Aplikasi Analisis Multivariate dengan program IBM SPSS 19 (edisi kelima), Universitas Diponegoro. Semarang.

Horne, James C. Van dan John M. Wachowicz, Jr. 2012. Prinsip-prinsip Manajemen Keuangan. Edisi Ke-13. Buku 1. Salemba Empat. Jakarta.

Kasmir, 2012. Analisis Laporan Keuangan. PT Raja Grafindo Persada. Jakarta.

Kadir, Abdul. 2010. Anlisis Faktor-Faktor Yang Mempengaruhi Kebijakan Dividen Pada Perusahan Credit Agencies Go Public Di Bursa Efek Indonesia. Jurnal Manajemen dan Akuntansi Volume 11 No 1. 
Marietta, Unzu. 2013. Analisis Pengaruh Cash Ratio, Return On Assets, Growth, Firm Size, Debt to Equity Ratio Terhadap Dividend Payout Ratio (Studi Pada Perusahaan

Manufaktur yang Terdaftar di Bursa Efek Indonesia Tahun 2008-2011).Skripsi. Universitas Diponegoro.

Sutrisno, 2009. Manajemen Keuangan Teori, Konsep dan Aplikasi. Ekonisia, Yogyakarta.

Sumiadji, 2011. "Analisis Variabel Keuangan yang Mempengaruhi Kebijakan Dividen pada

Perusahaan Manufaktur yang Terdaftar Di Bursa Efek Indonesia periode 2004-2008”. Jurnal Dinamika Akuntansi, Volume 3 No. 2 Hal 129-138. Malang: Politeknik Negeri Malang.

Weston dan Copeland. 1997. Manajemen Keuangan Jilid 2 Edisi 9. (Penerjemah: Jaka Wasana dan Kibrandoko. Jakarta: Binarupa Aksara.

Wahdah, Rofiqoh. 2011. "Analisis Faktor-faktor yang Mempengaruhi Tingkat Pengembalian Investasi pada Perusahaan Manufaktur Di Bursa Efek Indonesia". Jurnal Socioscientie, Volume 3 No. 2. Hal 309-320. Banjarmasin: STIE Indonesia. 